Genus Peltastes, Agass., 1838, amended. Syn. Hyposalenia, Desor.

Subgenus Goniophorus, Agass., 1838.

Genus Salenia, Gray, 1835, amended.

Subgenus Heterosalenia, Cott., 1861.

XVI.-On the Pelagic Fauna of our Shores in its Relation to the Nourishment of the Young Food-Fishes. By Prof. M'Intosh, M.D., LL.D., F.R.S., \&c.*

$\mathrm{Br}$ the term pelagic fauna is meant the inhabitants of the whole body of the water from the surface to the bottom. This immense area, it is well known, varies greatly in depth, viz. from 4655 fathoms (that is upwards of five miles), as sounded by the American exploring-ship 'Tuscarora,' near the Kurile Islands in the North-east Pacific, to a few inches, as on gently sloping sandy beaches.

The pelagic fauna of the surface of the ocean has for ages attracted the attention both of voyagers and of scientitic men. In the tropical and subtropical regions especially the abundance and variety of such animals are remarkable; yet they are not confined to these warmer areas, certain types, as copepods and pteropods, occurring in such countless multitudes in the arctic seas that they form the food of the right whales. The colder waters, just mentioned, however, do not, as a rule, present the brightly coloured and conspicuous swimmers of the warmer areas, such as Portuguese Men-of-war, Venus's Girdles, the exquisite siphonophores, pelagic annelids (e. g. Alciopa), and certain types of pteropods and crustaceans.

In our own seas, even the most superficial observer on the eastern coast must have been struck by the great beauty and abundance of the lilac Aurelice, the deep purple of the young or the rich brown of the adult Cyanea, frequently stranded in multitudes on sandy beaches in autumn; while in the milder waters off the western shores the greater variety of the purple and reddish medusæ (e. g. Pelagia, Equorea, Modeeria, Oceania), the occasional occurrence of such truly oceanic forms as Physalia, Velella, and Ianthina, the long chains of Salpæ, and the crystalline calices and orange polypites of

* Abstract of Introductory Lecture to the Class of Natural History, University of St. Andrews, November 13, 1886. 
Diphyes, besides other rare forms, make up a characteristic pelagic fauna.

In connexion with the consideration of the vast number of free oceanic animals near our own shores, a feature, perhaps not sufficiently appreciated, is the fact that a constant interchange takes place between the upper regions and the bottom, and this at very considerable depths*. So far, indeed, as present observations go, there is no reason why any region of the water, say between 200 fathoms or more and the surface, should be azoic + . Thus many of the deep-sea starfishes have larvæ which swim near the surface of the water, and they again descend when they have reached a stage in which the main features of the adults have been reproduced. Many of the Pleuronectidæ, such as the plaice, turbot, and craigfluke, which habitually live on the bottom, produce eggs which are truly pelagic and float near the surface of the water, as also do the early embryos. The young, however, as they grow older sink deeper and deeper in the water, until at a certain stage they take up their residence at the bottom, like their parents. Such animals, therefore, at different periods of their existence inhabit separate zones of the water, and thus form one of the great groups into which pelagic animals may be divided, viz. those Temporarily Pelagic, the other division being constituted by those Permanently Pelagic.

The area from which this temporary pelagic life is derived is extensive, for every patch of sponge covering rocks, stones, and seaweeds, many hydroid zoophytes and other cœlenterates, many echinoderms, the majority of the annelids, many Polyzoa and tunicates, and numerous shell-fishes, send off periodically a succession of ciliated free-swimming larvæ. Moreover, such occurs not only between tide-marks but wherever marine animals exist on the sea-bottom.

In briefly alluding to the various forms which people the region under consideration, on the east coast, it is found that besides the pelagic fauna there is a pelagic flora, the most abundant forms being diatoms and desmids, the former occurring: everywhere near the surface of the water, in the stomachs of pelagic animals in mid-water, and in the alimentary cavities of ascidians fixed to the bottom. The pelagic Foraminifera and radiolarians again are equally abundant at the surface and at the bottom, and the living as well as the dead may pass from the upper to the lower region of the water. The upper parts of the sea teem with Infusoria, such as Ceratium,

* Vide Report of H.M. Trawling Commissioners, 1884-5, p. 372 \&c.

+ Prof. Moseley is unable to give a decided opinion on this point, or thinks that a vast region may be azoic. 
Peridinium, and Tintinnus, and they are also present in the stomachs of annelids and other forms more or less fixed to the bottom. The free-swimming larvæ of the sponges, as formerly indicated, also materially augment the pelagic fauna.

Amongst cœlenterates the various true Medusæ with their larval forms are often in immense abundance, and so are the Hydromedusæ and their ciliated planulæ. The most common types of the Hydromedusæ are Thaumantias, Bougainvillia, Turris, Oceania, and the little zooids of Obelia, a zoophyte which forms a dense coating on the ropes of stake-nets for salmon and other submerged structures with considerable rapidity. In the same way the Zetlandic waters are occasionally rendered phosphorescent by multitudes of similar free buds. The ctenophores (Pleurobrachia and Beroë) are also often very abundant. In connexion with the occurrence of the foregoing colenterates, it is well to point out that they do not always come to the surface, indeed they may be in vast multitudes though not a single example is seen. As a rule, Medusæ of various kinds appear to pass their younger stages in the lower regions of the water, and only come upwards in certain seasons and under certain conditions. Their presence is often first discovered by the trawl, and subsequently they are noticed on a calm summer evening at the surface, which is broken here and there by their contractions. The reasons for this irregularity in the appearance of the Medusæ are not at present clearly understood, and they are not altogether due to atmospheric or oceanic causes.

The echinoderms, from holothurians to rosy feather-stars, add largely to the temporarily pelagic fauna, since the larvæ in most of the genera mount near the surface and only return to the bottom after the adult shape is assumed. The influence which even such forms as the Ophiuridæ, which generally live so buried in sand as to escape the trawl, have on the pelagic fauna is considerable, since their larval Plutei swarm near the surface.

The larval annelids, again, are almost universally pelagic, and off both sandy and rocky shores as well as everywhere on the bottom a vast number are annually set free. Some adults, again, as Toida and Tomopteris, are only found in a pelagic condition, and others assume it in special phases connected with reproduction. Sagitta follows the same habit, and is occasionally observed in enormous numbers, their bodies sparkling like endless lines of glassy needles as they are stranded by the tide on the beach. The larval annelids affect the whole body of the water, and the same may be said of Sagitta. 
The class Crustacea, as a rule, exceeds most of the other groups in the abundance and variety of its pelagic adults and pelagic larvæ. The tow-net, indeed, off the eastern shores in July and August is sometimes coated with a semisolid mass of their bodies, consisting of young cirripedes, copepods, larvæ of the common shore and edible crabs, porcelain crabs, and others, such as the common and Norway lobsters. These larvæ, as they descend to the bottom in their more advanced stages, may be reckoned as the fauna of all intermediate regions. Moreover, pelagic life is not confined to the larvæ, for the eastern bays occasionally swarm with such schizopods as Thysanoëssa tenera, G. O. Sars, and Nyctiphanes norvegica, M. Sars-Norwegian types discovered by the authors mentioned, the former being already known as British, while the latter, Dr. Merle Norman kindly informs me, for the first time appears on our list. Both forms occurred off the east coast, and especially in St. Andrews Bay, towards the end of April, and so densely that the tidal wave was crowded with them, and miles of sand were strewed with their bodies which the receding wavelets left in streaks and curves*. Various sessile-eyed crustaceans also occasionally occur at the surface, such as Amphithö̈, Lestrigonus, Lysianassa, besides many Ostracoda and the young of Diastylis. Moreover the young of Caligus are sometimes in great abundance off rocky margins, and thus are ready to settle on the various food-fishes, none being more liable to attack than the cod.

Amongst the Molluscoida the ciliated larvæ of the Polyzoa and the tailed larvæ of many tunicates increase the pelagic fauna, especially in rich inshore regions; while Appendicularia is frequent in the tow-net both there and in the open sea. The eastern coast, however, presents a great contrast to the western in the entire absence of Salpæ, the chains of which sometimes occur in countless multitudes in the warm Gulfstream bathing the Outer Hebrides.

The larval Mollusca are generally pelagic, and this is especially the case with the bivalves which inhabit sandy flats. Few, moreover, have any conception of the enormous numbers of the larval musseis alone which are poured into the various bays and the water beyond every year; though an idea of their abundance may be obtained by inspecting the solid mass which they form in the tow-net, or the rocks and zoophytes (Obelia, Gemellaria, \&c.) at a somewhat later stage when assuming a sedentary existence. The pteropods (Spirialis) of the eastern waters, again, are pelagic throughout

* When dried they closely resembled chaff, for which, indeed, the uninitiated took them. 
life, and they sometimes shun the upper waters for lengthened periods, being found only in the lower stratum, both by night and by day. As a rule, however, voyagers have captured them most abundantly in the tow-nets in the evening. D'Orbigny's pleasant but fanciful description of the habits of these forms is inadequate to explain such phenomena. Lastly, the larvæ of the cuttlefishes, which on the eastern coast deposit their eggs on the bottom, shoot upward into the water on emergence, and are as lively as the adults in ordinary circumstances are sluggish.

From the foregoing brief and somewhat imperfect summary it will be apparent that the animals which constitute the invertebrate pelagic fauna are both numerous and varied; and as the representatives of almost every group are more or less adapted to form the food of other types or even of its own, it follows that there is abundance of nourishment of this kind in the inshore and neighbouring waters, as well as in many parts of the open sea.

Further, the young food-fishes themselves form important members of the pelagic fauna. Almost every food-fish, indeed, passes through the pelagic phase, either temporarily as a pelagic form or remaining so throughout life, like the herring, the pilchard, and the mackerel. It is true the ova of the herring are deposited on and glued to the bottom; but the larval fish rises, as soon as it gains sufficient strength, to the upper regions of the water. Again, with the exception just mentioned and a few others, the majority of the Teleostean food-fishes produce ova which mount in still water to the surface or near it in more restless seas. The young are there hatched in a very incomplete state, generally without a mouth, and subsist for some days on the store of nourishment in the small yolk-sac *. They are carried about in a helpless condition by the surface-currents, but probably do not proceed very far from the area in which they emerged. Before the absorption of the yolk-sac the mouth has formed and the little fish, already full of activity, is in a condition to prey on the more minute forms around it.

Introduced into life from pelagic eggs and in the midst of pelagic surroundings, the young of the food-fishes much resemble each other in general outline, though there are certain characters, chiefly specks of pigment, which enable the zoologist to discriminate them. Each has a marginal fin commencing behind the nape of the neck and running vertically to the tail, which it includes, and then forward along

*Vide E. E. Prince, "Development of Food-Fishes," Ann. \& Mag. Nat. Hist., May and August 1886, 
the lower margin to the yolk-sac. The pectorals are nearly alike, and the ventrals are generally absent. Thus the young cod, haddock, whiting, ling, rockling, gurnard, flounder, dab, turbot, plaice, and others have a tolerably close resemblance. They are all nourished in this tadpole-stage by the small yolk-sac, and thereafter find the same minute food in the sea around them. Yet the five former chiefly seek in adult life the bottom waters; the sixth is a mid-water or bottom fish ; while the four last-named are characteristically so, often lying buried in the sand.

During growth various modifications take place in the young fishes, some of them being probably adapted for their temporary sojourn in the upper regions of the water, while others may be due to heredity. As development of the muscular and other systems proceeds, and as each little fish acquires greater powers of locomotion, the fins most used in balancing increase in size. Thus the pectorals of the young salmon, cod, haddock, whiting, and especially the gurnard are disproportionately large in the succeeding stage, probably because such enables them to capture their pelagic prey more readily and with greater certainty. Their heads and eyes are also comparatively large.

In connexion with the development of the fins it is interesting that some pelagic fishes, whose habits at present are vaguely known, are remarkable for certain peculiarities in their fins. Thus, in the oar-fish (Regalecus Banksii) the pectorals are of moderate size, while the slender ventrals are enormously elongated and tipped with a flattened blade, so that in outline they somewhat resemble a painter's maul-stick. It is not known whether the fish uses these as tactile organs, as the hump-backed whale is said to use its great flippers, to avoid being beached, or otherwise; but they would appear to form an efficient means for sounding the distance from the bottom or other solid structure.

Now a remarkable change takes place in the fins of two well-known fishes, one of which is of considerable commercial importance, viz. the ling; and further examination will probably reveal a similar condition in other forms, such as the cod. Indeed Alex. Agassiz * figures a young fish with attenuate and elongate ventrals, and which he conjectures to be a young cod.

After the early tadpole-stage of the ling already mentioned, and in which it corresponds in outline with the young of other food-fishes, though it is differentiated by peculiar dull yellow pigment, it seeks its way downward as it grows larger.

* Proc. Amer. Acad. Nat. Sc. xvii. p. 296, pl. viii. figs. 4 and 5. 
Thus it is found at a depth of 25 fathoms on 32 -fathom ground ( $i$. e. about 7 fathoms from the bottom) as a little fish having the form of the adult but with a pair of enormous ventral fins (like those of the young sword-fish *) of a deep yellow colour, the only remnant of the tint so characteristic of the tadpole-stage. It would appear to be a truly pelagic stage of a bottom fish, for it is doubtful if the long ventrals would be of much use to an active fish that seeks its prey on or near the ground. The other larval fish characterized by long ventrals is the rockling $t$, and it is noteworthy that these are likewise conspicuously coloured, being white at the base and black at the tip. The rockling, like the ling, haunts the bottom in adult life, while it is truly pelagic in its larval stages. Too little is yet known in regard to the influence of such elongate ventrals on the habits of these young fishes to enable a correct judgment to be formed; but it would appear to be, in part at least, connected with their more active existence. In the same way the huge pectorals of the larval gurnard (which cause it to mimic the flying gurnard) can be explained. An analogous condition is seen even in the pectorals of the larval catfish (in which, of course, ventrals are entirely absent), and their tails are also proportionally larger than in the adult, thus enabling them to mount readily through a considerable stratum of water, though they are hatched on the bottom and ultimately live there. In estimating the influence of such modified organs it is well to bear in mind that at a later stage and with much shorter fins certain fishes, such as the cod and haddock, procure similar (pelagic) food, but at a distance from the surface and in the midst of different currents. Their muscular systems, however, are much more largely developed $\ddagger$.

The special bearings of the wealth of pelagic life on the nourishment of the young food-fishes now fall to be considered.

* In this stage the little ling at first sight approaches the condition in the forked hake, for which Mr. Calderwood and I for a moment took it. The larval angler also shows huge ventrals, while in the adult they are small. The dory, again, has long ventrals in its adult stage.

$\dagger$ First pointed out by Alex. Agassiz in a form which he doubtfully referred to Moteila argentea (Proc. Amer. Acad. of Arts \& Sci. vol. xvii. p. 294 , pl. vii.).

$\ddagger$ Zoologists had been so accustomed to consider the greatest wonders of the sea to be on the bottom that the novelties in the superincumbent water had been somewhat under-estimated. Yet it is only in the latter region that the mysteries still present in the life-histories of many of the food-fishes can be unravelled and the direct and indirect influences exercised by other pelagic forms on their growth duly appreciated. It is in this connexion that the huge mid-water net attached to the large triangle (vide Ann. \& Mag. Nat. Hist. for Oct. 1886, p. 310) will be of real service to science. 
On glancing at the various forms of pelagic animals it is found that both those which are temporarily and those which are permanently pelagic are important factors in the food of fishes. The temporarily pelagic include such forms as larval stages of sponges, hydromedusæ, and larval cœlenterates, larval stages of starfishes, annelids, crustaceans, molluscoids, and mollusks, as well as the ova and young of fishes. The other or permanently pelagic group may be represented by the ctenophores, certain medusæ, copepods, schizopods, and other crustaceans, Tomopteris and other annelids, pteropods, certain cephalopods, and fishes. Some of the small forms, such as diatoms, Infusoria, larval medusæ, and starfishes, are rare in the stomachs of the minute food-fishes; but still the first two are occasionally found there. Moreover they are devoured by the crustaceans and mollusks, which subsequently nourish the fishes. Two groups especially stand out as universally distributed constituents of the food of the young fishes, viz. the crustaceans and the mollusks. The former is by far the most general at a very early stage; the latter is more characteristic of the later stages.

It is an interesting fact that at the time when the pelagic ova give birth to the young food-fishes the ocean especially abounds with the minute forms of the Crustacea, such as young copepods and the larvæ of other groups *. As soon as the yolk-sac is absorbed, and even before it is wholly absorbed, the most minute (almost microscopic) specimens of such crustaceans are found in the stomachs of the little fishes. Moreover this food is almost universal, for not only the young of the round and flat fishes (which keep up the relish for crustaceans in adult life), but the young of such forms as Cyclopterus lumpus, which, when full-grown, rarely feeds on crustaceans, and the young of Lophius piscatorius, which is strictly a destroyer of fishes in after life, follow the same habit. Nor is this food confined to their sojourn near the surface. As they grow older they descend to the lower water, where the same nourishment abounds, and there the young cod, haddock, whiting, ling, gurnard, and others disport themselves in the unceasing pursuit. The young flat-fishes accompany them, still swimming on edge and with an eye on each side, but being readily recognized by certain peculiarities, amongst which is the greater depth of the body. The nature of the food in many cases is indeed recognized with tolerable certainty at first sight, since in the more advanced larvæ the crustaceans (e. g. Calanus finmarchicus) tint the under surface of the translucent abdomen of a delicate pinkish hue.

* In this respect there is a parallelism with the atmosphere and insectlife in summer and autumn. 
It is probably the profusion of crustacean life close inshore that tempts the shoals of green cod, common cod, whiting, and pollack to seek the rock-pools and inlets at low water; there they pursue their active prey amongst the olive-green seaweeds and forests of tangles, and likewise seize on many of the smaller Mollusca browsing on the algæ. These large forms also to a considerable extent feed on the young mussels just as they are quitting pelagic life to fix themselves by their byssi to the seaweeds, zoophytes, and rocky surfaces; and no food is more eagerly sought after or is more nourishing than this. Their enormous numbers, for instance in St. Andrews Bay, make them important elements in the food of the younger fishes; and though perhaps their presence is not so vital as that of the minute crustaceans in the early larval stage, still any serious injury to the fine mussel-beds of the Eden or of the Tay would be detrimental to the prosperity of the fisheries. Man has this much in his power; but he is impotent in regard to the vast and never-failing supply of minute crustaceans and other forms which Nature provides in the open sea for the sustenance of the delicate and translucent young of the foodfishes. No ordinary atmospheric change can materially modify this wealth of pelagic life, though it is true that in some seasons its appearance and that of the young fishes which prey on it may be slightly varied.

The importance of the pelagic element in the food of our fishes cannot readily be over-estimated. Without it the young fishes, after the absorption of the yolk-sac, would become emaciated and perish. Moreover the minute size of certain of the constituent forms is eminently adapted for the needs of the most tiny fishes; while the adults of the same crustaceans, or those of more bulky species, fit in as suitable sustenance of young fishes of larger size. The interchange, again, taking place between the bottom-fauna and the surface, viz. of eggs and early larvæ passing upward, and of older forms going downward, keeps up a constant stream of food for the young fishes, which have a similar migration. But they do not, unmolested, thus levy a tax on the lower types. The larger food-fishes prey perpetually on the smaller; indeed certain stages in the development of the rarer fishes have hitherto been procured only from the stomachs of predaceous pelagic fishes, such as the various tunnies. In the same way early stages of haddock, whiting, and herring drop from the mouths of cod when landed on deck from the trawl. Thus a check is kept on the enormous powers of reproduction so characteristic of the food-fishes-powers of reproduction which have hitherto been, and doubtless will continue to be, of great benefit to man.

Ann. \& Mag. N. Hist. Ser. 5. Vol. xix. 

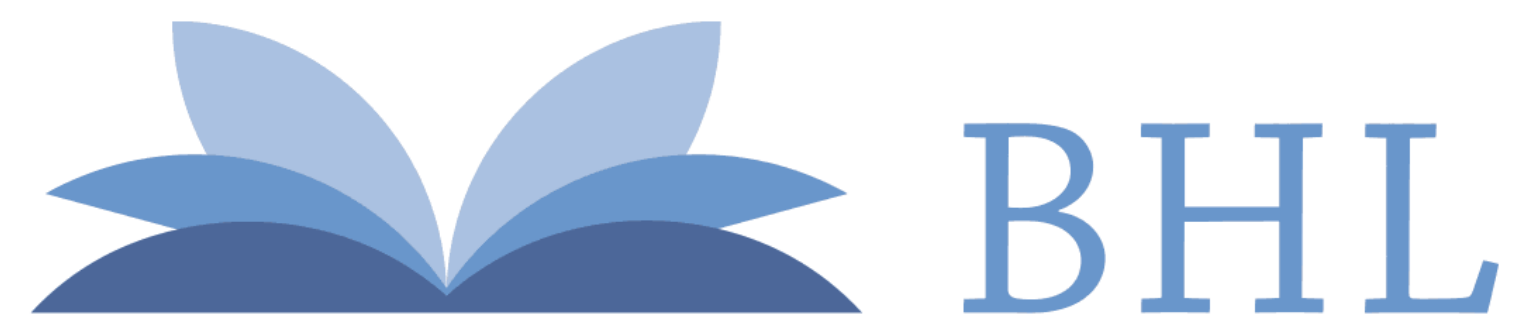

\section{Biodiversity Heritage Library}

M'Intosh, William Carmichael. 1887. "XVI.-On the pelagic fauna of our shores in its relation to the nourishment of the young food-fishes." The Annals and magazine of natural history; zoology, botany, and geology 19, 137-145. https://doi.org/10.1080/00222938709460211.

View This Item Online: $\underline{\text { https://www.biodiversitylibrary.org/item/55145 }}$

DOI: https://doi.org/10.1080/00222938709460211

Permalink: https://www.biodiversitylibrary.org/partpdf/56981

\section{Holding Institution}

Smithsonian Libraries

\section{Sponsored by}

Smithsonian

\section{Copyright \& Reuse}

Copyright Status: Public domain. The BHL considers that this work is no longer under copyright protection.

This document was created from content at the Biodiversity Heritage Library, the world's largest open access digital library for biodiversity literature and archives. Visit BHL at https://www.biodiversitylibrary.org. 